\title{
Konfrontasi Amerika Serikat dan Iran dalam Joint Comprehensive Plan of Action (JCPOA)
}

\author{
Satwika Paramasatya dan Sigit Wiranto \\ Universitas Diponegoro
}

\begin{abstract}
ABSTRAK
Kesepakatan Nuklir Iran atau Joint Comprehensive Plan of Action (JCPOA) merupakan hasil perundingan diplomatis yang dicapai AS, Inggris, Perancis, Rusia, Tiongkok, Jerman dan Iran pada tahun 2015. Terpilihnya Donald Trump sebagai presiden AS membawa kebijakan baru terkait isu nuklir Iran. 8 Mei 2018 AS secara resmi menarik diri secara sepihak dari kesepakatan nuklir dan memutuskan untuk kembali menerapkan sanksi terhadap Iran. Tujuan dari penulisan penelitian ini adalah untuk menganalisis faktor penyebab AS merubah kebijakannya untuk keluar dari kesepakatan nuklir dengan pendekatan analytic eclecticism yang memadukan konsep security dilemma dengan teori cognitive consistency. Hasil penelitian ini adalah penarikan diri AS dari JCPOA secara psikologis disebabkan konsistensi pemikiran Trump yang memandang kesepakatan nuklir Iran sebagai kesepakatan yang buruk dan tidak bisa diandalkan karena di bawah kesepakatan nuklir AS dan sekutunya masih merasakan dilema keamanan yang kemudian mendorong Trump berupaya untuk menekan Iran dengan keluar dari kesepakatan nuklir.
\end{abstract}

Kata-kata kunci : Kesepakatan Nuklir Iran, JCPOA, Dilema Keamanan, Konsistensi Kongnitif, Eklektisme Analitis

Iran Nuclear Agreement or Joint Comprehensive Plan of Action (JCPOA) was the result of diplomatic negotiations achieved by the United States, United Kingdom, France, Russia, China, Germany, and Iran in 2015. The newly elected president of the United States Donald Trump brought new policies to the Iran's nuclear issue. On May 8, 2018 The US government unilaterally withdraw themselves from the JCPOA agreement and decided to reimpose the sanctions for Iran. This research tries to analyze why the US changed its policy to withdraw from the nuclear agreement by using analytic eclecticism, with the combination of the security dilemma and cognitive consistency theory. The result of this research shows that the US' withdrawal from JCPOA psychologically caused by Trump's cognitive consistency. He thought that Iran's nuclear agreement is a bad and unreliable agreement because under this nuclear agreement, US and its allies still feel the security dilemma. Therefore, it pushed Trump to increase the pressure to Iran by withdrawing themselves from the nuclear agreement.

Keywords: Iran Nuclear Agreement, JCPOA, Security Dilemma, Cognitive Consistency, Analytic Eclecticism 
Kesepakatan Nuklir Iran atau dikenal dengan Joint Comprehensive Plan of Action (JCPOA) merupakan hasil perundingan diplomatis yang dicapai oleh Amerika Serikat, Inggris, Perancis, Rusia, Tiongkok, Jerman dan Iran pada tahun 2015. Munculnya kesepakatan ini disebabkan oleh tindakan Iran yang menyalahgunakan pengembangan nuklirnya untuk dijadikan sebagai senjata pemusnah masal pada tahun 2011 (Nainggolan 2015). Menyikapi hal tersebut negara-negara Barat menjatuhkan sanksi ekonomi kepada Iran dengan harapan dapat memperlemah posisi Iran sehingga tidak memiliki kemampuan untuk melanjutkan program senjata nuklirnya. Pada kenyataannya sanksi tersebut berhasil untuk melemahkan perekonomian Iran namun tidak cukup efektif secara politik sebab pemerintahan Iran tetap kuat, hal ini menyebabkan Iran masih terlibat dalam berbagai konflik di kawasan dan masih bersikeras mengembangkan pengayaan uraniumnya (Saïd 2016). Sikap keras Iran membuat negara-negara Barat memilih untuk membawa Iran ke dalam perundingan dengan memberikan penawaran yang dapat menarik perhatian Iran. Pada masa pemerintahan Obama, Amerika Serikat berhasil membawa Iran masuk ke dalam perundingan. Komitmen Iran yang kuat untuk memiliki senjata nuklir menjadi permasalahan bagi negara-negara besar. JCPOA atau dikenal dengan Kesepakatan Nuklir Iran merupakan jalan keluar yang diambil oleh AS, Inggris, Perancis, Rusia, Tiongkok dan Jerman dalam mengatasi polemik kepemilikan senjata nuklir Iran.

Terpilihnya Donald Trump sebagai pemimpin baru Amerika Serikat membawa kebijakan baru terkait isu nuklir Iran. Pada 8 Mei 2018 Amerika Serikat secara resmi menarik diri dari kesepakatan nuklir dan memutuskan untuk kembali menerapkan sanksi terhadap Iran (Telegraph 2018). Keluarnya Amerika Serikat dari kesepakatan nuklir Iran merupakan keputusan sepihak yang tidak melibatkan para anggota penandatangan kesepakatan lainnya. Kesepakatan itu masih dipandang oleh negara-negara lain sebagai cara terbaik untuk mencegah Iran menjadi sebuah negara yang memiliki kekuatan nuklir, meskipun mereka mengakui bahwa kesepakatan yang sudah terbentuk masih belum sempurna (BBC 2018). Meski mendapat dukungan dari sekutunya di Timur Tengah, kebijakan Amerika Serikat yang kontroversial ini ditentang oleh banyak pihak, termasuk negara yang terlibat dalam kesepakatan. Bahkan tanpa Amerika Serikat negara penandatangan masih berkomitmen untuk melanjutkan kesepakatan sebab tidak ingin membiarkan Iran lepas kendali (Telegraph 2018). 
Keluarnya Amerika Serikat dari kesepakatan membuat kesepakatan nuklir Iran berada dalam posisi yang rentan. Pihak penandatangan yang masih bertahan dituntut untuk dapat melindungi Iran dari sanksi yang kembali diterapkan Amerika Serikat. Di sisi lain Iran semakin mempertegas pendiriannya bahwa kesepakatan nuklir Iran adalah kesepakatan yang tidak bisa lagi dinegosiasikan. Meningkatnya ketegangan antara Iran dan Amerika Serikat kini membawa konsekuensi langsung terhadap ancaman Iran yang ditujukan kepada Amerika Serikat dan sekutu terdekatnya di Timur Tengah, kondisi ini semakin meningkatkan eskalasi konflik kawasan.

Kekhawatiran yang menjadi polemik dalam JCPOA adalah bahwa Iran akan menggunakan keringanan sanksi untuk membangkitkan kembali ekonominya. Iran dianggap tidak mungkin melepaskan status hegemon regionalnya sekalipun Iran ingin memprioritaskan manfaat ekonomi dari perdagangan minyak dalam jangka pendek, perdagangan ini kemungkinan besar akan dieksploitasi untuk kepentingan politik dalam jangka panjang. Seiring berjalannya waktu, Iran juga berhasil untuk tetap menjaga program nuklirnya pada tingkat yang tinggi sehingga kemudian membuat JCPOA berjalan tidak seimbang. Iran terlihat sebagai pihak yang lebih unggul dan diuntungkan sebab setelah JCPOA berakhir, negara tersebut berpotensi untuk mendapatkan senjata pemusnah masal (weapon of mass destruction/WMD) dan pada saat itu, ekonominya akan berada dalam kondisi yang lebih baik dan pengaruh regionalnya bahkan lebih besar sehingga kesepakatan itu pada akhirnya akan menguntungkan Iran secara sepihak. Dalam pidatonya di Sidang Umum PBB pada 19 September 2017, Presiden Trump mengatakan:

"We cannot let a murderous regime continue these destabilizing activities while building dangerous missiles, and we cannot abide by an agreement if it provides cover for the eventual construction of a nuclear program. The Iran Deal was one of the worst and most one-sided transactions the United States has ever entered into. Frankly, that deal is an embarrassment to the United States, and I don't think you've heard the last of it, believe me." (White House Office of the Press Secretary 2017).

International Atomic Energy Agency (IAEA) sejak tahun 2016 telah merilis verifikasi yang dilakukan setiap tiga bulan sekali dan laporan pemantauan tentang implementasi Iran terhadap ketentuan JCPOA berdasarkan UNSCR 2231. Laporan-laporan tersebut secara konsistenmenunjukkankepatuhanIrandalammengimplementasikan JCPOA (IAEA 2016). AS pada bulan Agustus 2017 menjatuhkan 
sanksi baru terhadap Iran dengan anggapan bahwa Iran terlibat mendukung kelompok militan dan mengembangkan rudal balistik yang melanggar ketentuan kesepakatan nuklir dan resolusi PBB. Sanksi tersebut dianggap Iran sebagai pelanggaran terhadap kesepakatan, Iran justru merespons balik dengan meyusun RUU peningkatan anggaran pengembangan rudal sebagai isyarat bahwa mereka akan tetap mengembangkan rudal mereka, tidak peduli terhadap kecaman dan sanksi yang dijatuhkan AS (Suastha 2017).

Trump menyatakan bahwa Kesepakatan Iran seharusnya berkontribusi pada perdamaian dan keamanan regional bahkan internasional. Bagi Trump, AS telah mematuhi komitmennya tetapi rezim Iran masih tetap melakukan tindakan-tindakan yang mendestabilisasi kawasan Timur Tengah dengan memicu konflik, terror dan kekacauan. Untuk mengatasi hal tersebut maka pemerintahan Trump bersama Kongres dan sekutu berupaya untuk mengatasi kekurangan yang ada dalam kesepakatan sehingga Iran tidak lagi dapat mengancam dunia dengan senjata nuklir. Jika upaya tersebut tidak menghasilkan solusi maka AS menyatakan JCPOA akan berakhir, dan Trump sebagai presiden dapat melakukan pembatalan partisipasi kapan pun ia ingin. Pada 12 Januari 2018, Presiden Trump kembali mengancam akan menarik Amerika Serikat dari JCPOA kecuali Kongres dan sekutu Eropa memperbaiki kelemahan yang ada dalam kesepakatan nuklir Iran, termasuk meminta penghapusan tanggal kedaluwarsa untuk pembatasan nuklir JCPOA di Iran dan menekan pengembangan dan rudal balistik Iran dengan sanksi berat. Trump tidak mendapatkan solusi atas permasalahan yang ia keluhkan kemudian pada akhirnya tanggal 8 Mei 2018, Trump mengumumkan bahwa AS berhenti menerapkan JCPOA dan kembali menerapkan sanksi terhadap Iran yang sebelumnya ditangguhkan sebab diberlakukannya JCPOA.

\section{Dilema Keamanan dan Keluarnya AS dari JCPOA}

Sebagai wilayah yang rentan terhadap konflik Timur Tengah tidak luput dari perhatian dunia, untuk menjaga keamanan di wilayah tersebut negara-negara berupaya membangun aliansi regional dan internasional untuk melindungi dan memperkuat keamanan mereka. Situasi tersebut memaksa negara-negara non regional untuk turut mengambil peran di Timur Tengah. Tidak terkecuali AS, negara besar yang kehadirannya sangat jelas di wilayah Timur Tengah dengan berbagai upaya intervensi dalam urusan regional 
dan penempatan pasukan militernya di banyak lokasi di kawasan Timur Tengah. Kehadiran AS ini justru dianggap berkontribusi terhadap memburuknya keamanan regional Timur Tengah. Dominasi AS mungkin dapat memaksa negara lain untuk menerima kepemimpinannya, tetapi rezim Iran tidak pernah menerima atau mengakui hal tersebut. (Erik Slavin 2014).

Ditengah kerentanan dan ketidakpastian yang ada dikawasan mendorong negara-negara untuk melindungi kepentingannya sendiri karena tidak ada jaminan yang pasti terhadap masa depan keamanan mereka. Peningkatan kekuatan militer di Timur Tengah telah menciptakan masalah keamanan, yang memaksa negaranegara kawasan untuk mencoba melindungi dan mempertahankan keamanan nasional mereka dari berbagai ancaman. Iran sebagai negara yang dianggap musuh bersama oleh negara-negara Arab, sangat merasa perlu untuk menjamin keberlanjutan hidup negaranya dari ancaman eksternal. Salah satu upaya yang dilakukan Iran adalah dengan mempersenjatai diri, termasuk upaya memiliki senjata nuklir. Di bawah kondisi dilema keamanan, negara khawatir diserang atau didominasi oleh pihak lain dan ini membuat mereka berupaya meningkatkan kekuatan untuk menghindari pengaruh kekuatan pihak lain. Pada gilirannya, situasi ini memungkinkan pihak lain lebih merasa tidak aman dan memaksa mereka untuk bersiap menghadapi kemungkinan terburuk (Berni 2018).

AS dan sekutunya di Timur Tengah memiliki rekam jejak hubungan yang tidak harmonis dengan Iran. Posisi Iran di Timur Tengah yang dianggap sebagai hegemon turut menambah kakhawatiran bagi AS dan sekutunya berkaitan dengan perilaku Iran yang dianggap mendestabilisasi kawasan dengan berbagai kekacauan yang diakibatkan oleh perilaku Iran. Sikap antagonis yang dimiliki masing-masing negara ini kemudian tidak dapat memberikan rasa percaya satu sama lain. Ketika Iran berupaya untuk mengembangkan senjata nuklir, tidak hanya AS dan sekutu terdekatnya di Timur Tengah yang merasa terusik keamanannya, bahkan negaranegara lain yang tergabung dalam Dewan Keamanan PBB turut berupaya untuk menghalangi Iran memiliki senjata nuklir. Untuk saat itu dapat dikatakan bahwa AS sedikit lebih merasa tenang dengan keberhasilannya mengekang program nuklir Iran melalui JCPOA. Meski demikian Israel masih belum merasa puas dengan kesepakatan yang telah dicapai. Seiring berjalannya waktu ketika JCPOA telah secara legal diimplementasikan Iran secara konsisten mematuhi komitmennya dalam menjalankan kesepakatan. 
Trump berfokus untuk mendukung sekutu tradisional Amerika Serikat dan melawan saingan tradisionalnya. Ia berupaya membatasi atau menghentikan keuntungan bagi Iran yang berasal dari JCPOA, dan mengekspose kekurangan kesepakatan yang tidak pernah mengkaji peran regional Iran sebagai kekuatan yang mendestabilisasi. Hal ini didasarkan pada pernyataan Arab Saudi yang menggambarkan Republik Islam Iran sebagai pengekspor terorisme dan ketidakstabilan di seluruh kawasan, Saudi dengan tegas menyalahkan Iran sebagai dampak dari ancaman yang dirasakan. Untuk peran regionalnya, Iran telah dituduh memiliki niat agresif terkait dengan pengembangan program rudal balistiknya (Ahmadian, 2018). Dilema keamanan tidak berhenti dengan tercapainya JCPOA, namun ancaman tetap dirasakan AS dan sekutunya di Timur Tengah terlebih ketika Iran melakukan uji coba rudal balistik. Trump yang terpilih menggantikan Obama memberikan perhatian lebih pada kasus tersebut, dibawah administrasinya Trump mengkaji ulang kesepakatan nuklir yang telah terbentuk. AS dalam posisinya sebagai pihak yang terlibat dalam kesepakatan tidak diperkenankan menjatuhkan sanksi baru ketika Iran melewati proses verivikasi IAEA dengan hasil yang baik. Hal tersebut menghalangi retorika Trump dalam melakukan intervensi terhadap Iran.

Berdasarkan data yang diperoleh dari situs global fire power, Iran masuk dalam peringkat 3 besar kekuatan militer di wilayah regional Timur Tengah. Sebuah kekuatan yang cukup untuk diperhitungkan dan diwaspadai. Iran bisa mandiri dalam banyak bidang produksi senjata konvensional dan non konvensional. Dalam hal senjata konvensional, Iran memiliki program-program canggih, peralatan manufaktur, dan teknologi, karena kehadiran para ahli dari Rusia, Cina, Korea Utara, Ukraina, Belarusia misalnya, untuk membantu memperluas pembuatan sektor militernya (Katzman 2018).

Dilema keamanan berkembang menjadi sebuah masalah ketika muncul ancaman potensial yang diyakini dapat membahayakan, jika dibandingkan dengan kepemilikan senjata nuklir ataupun rudal balistik negara-negara sekutunya AS lebih khawatir dengan potensi bahaya yang muncul dari Iran, sebab AS percaya bahwa sekutusekutunya tidak mungkin mengarahkan senjata mereka untuk menyerang AS. Respon sebaliknya diberikan kepada Iran, yang memang dianggap sebagai bahaya yang mengancam kepentingan AS dan sekutunya. Keputusan AS untuk keluar dari JCPOA merupakan kebijakan kontroversi yang menuai berbagai respons dari dunia Internasional. Dalam hal ini AS dan sekutunya merasa 
kesepakatan nuklir Iran masih belum bisa menghentikan perilaku Iran yang mengancam, ancaman Iran direspons melalui penekanan keras dengan keluar dari JCPOA. Dilema keamanan yang terjadi di kawasan Timur Tengah dalam hal ini berpengaruh sebagai faktor eksternal yang membentuk respons AS terhadap aktifitas Iran yang menimbulkan ketidakamanan yang terjadi di kawasan, hal ini kemudian menyebabkan AS memilih untuk bertindak lebih tegas dalam menghadapi ancaman yang dirasakan dari Iran.

\section{Cognitive Consistency Donald Trump}

Dalam beberapa kasus, para pembuat keputusan memiliki keterbatasan pada kemampuan mereka untuk merumuskan kebijakan berdasarkan model rasional. Seperti halnya Donald Trump dalam mengambil keputusan untuk keluar dari kesepakatan nuklir Iran. Bagian ini menjelaskan apa yang menyebabkan para pengambil keputusan menyimpang dari ide rasional dan menuju model pengambilan keputusan yang lebih berbasis kognitif yang cenderung dianggap "irasional". Untuk menjelaskan hal tersebut dibutuhkan analisis aspek kognitif yang dimiliki Trump dengan terfokus pada images and beliefs yang ia miliki terkait kesepakatan nuklir Iran. Premis utama dari teori cognitive consistency adalah pembuat kebijakan terlalu memberi perhatian lebih terhadap apa yang ia yakini dan cenderung mengabaikan alternatif lain yang juga penting. Tidak peduli siapa dan darimana informasi yang diterima, pembuat keputusan tersebut tetap bertahan pada keyakinan sebelumnya. Bahkan menyingkirkan apa yang bertentangan dengan images and beliefs yang ia pegang.

Donald Trump dengan latar belakang seorang pebisnis yang sebelumnya tidak pernah memegang jabatan publik terjun menjadi politisi, selama masa kampanye nya menyatakan bahwa "the nuclear pact is a "disaster" and "the worst deal ever negotiated" it could lead to a "nuclear holocaust". Dalam pidatonya di depan kelompok lobi pro-Israel AIPAC pada bulan Maret 2016, Trump menyatakan bahwa yang menjadi prioritas utamanya adalah untuk membongkar kesepakatan dengan Iran yang membawa bencana bagi AS dan sekutunya di Timur Tengah (Reuters 2016). 
"I came here to speak to you about where I stand on the future of American relations with our strategic ally, our unbreakable friendship and our cultural brother, the only democracy in the Middle East, the state of Israel. My number-one priority is to dismantle the disastrous deal with Iran.

I have been in business a long time. I know deal-making. And let me tell you, this deal is catastrophic for America, for Israel and for the whole of the Middle East. I've studied this issue in great detail, I would say actually greater by far than anybody else.

Iran has already, since the deal is in place, test-fired ballistic missiles three times. Those ballistic missiles, with a range of 1,250 miles, were designed to intimidate not only Israel, which is only 600 miles away, but also intended to frighten Europe and someday maybe hit even the United States. And we're not going to let that happen. We're not letting it happen. And we're not letting it happen to Israel, believe me". (Time 2016)

Trump dalam pidatonya tersebut juga menyebutkan bahwa dirinya telah mempelajari isu tersebut dengan sangat detail, lebih jauh dari yang pernah dilakukan oleh orang lain. Mengungkit latar belakangnya sebagai pebisnis ia mengklaim dirinya sangat memahami betul bagaimana membuat kesepakatan dan menyimpulkan bahwa apa yang telah dicapai AS dan Iran bukanlah sesuatu yang menguntungkan.

Ketika Trump menjabat sebagai presiden AS, tidak ada perubahan pandangan terhadap kesepakatan nuklir Iran. Bahkan sesegera mungkin ia mengumumkan strategi barunya terhadap rezim Iran yang akan jauh lebih mewakili kepentingan AS. Trump menganggap bahwa JCPOA telah menghalangi keberhasilan AS dalam menghancurkan rezim Iran secara menyeluruh melalui keringanan dan pencabutan sanksi yang dilakukan.

"History has shown that the longer we ignore a threat, the more dangerous that threat becomes. For this reason, upon taking office, I've ordered a complete strategic review of our policy toward the rogue regime in Iran. That review is now complete. 
But the previous administration lifted these sanctions, just before what would have been the total collapse of the Iranian regime, through the deeply controversial 2015 nuclear deal with Iran. This deal is known as the Joint Comprehensive Plan of Action, or JCPOA.

As I have said many times, the Iran Deal was one of the worst and most one-sided transactions the United States has ever entered into. The same mindset that produced this deal is responsible for years of terrible trade deals that have sacrificed so many millions of jobs in our country to the benefit of other countries. We need negotiators who will much more strongly represent America's interest" (White House 2017).

Trump sangat berpegang teguh pada pandangan yang sudah ia miliki dan berusaha untuk meminimalisir pandangan-pandangan yang bertentangan dengannya. Hal tersebut dapat dilihat melalui pelengseran Sekretaris Negara Rex Tillerson yang kemudian digantikan oleh Direktur Central Intelligence Agency (CIA) Mike Pompeo, seseorang yang sangat mengkritik keras JCPOA dan menganggap kesepakatan tersebut merupakan "bencana". Trump memberikan keterangan bahwa perbedaan opini mereka dalam menyikapi kesepakatan nuklir Iran menjadi alasan yang menyebabkan Rex Tillerson dipecat.

"Rex and I have been talking about this for a long time We got along, actually, quite well, but we disagreed on things," Trump said. "Look at the Iran deal. I think it's terrible; I guess he felt it was OK. I wanted to either break it or do something, and he felt a little bit differently. So we were not really thinking the same" (Time 2018).

Setelah turun dari jabatannya Tillerson membuat pernyataan bahwa sebenarnya dia tidak mengharapkan AS meninggalkan kesepakatan nuklir tetapi Presiden AS harus membuat keputusan tersebut dan pada akhirnya, itulah yang ingin dia lakukan (McLaughlin, 2018). Penasihat Keamanan Nasional AS, McMaster juga digantikan posisinya sebab memiliki pandangan yang berbeda dengan Trump terkait JCPOA."McMaster was said to be forthright in arguing that President Trump should not scrap the Obama-era nuclear agreement with Iran". (BBC 2018). Dalam administrasinya Trump juga ditentang oleh Menteri Pertahanan, James Mattis mengganggap bahwa JCPOA memang perlu untuk dipertahankan sebab ketentuan di dalamnya memuat kepentingan AS, berbeda dengan Trump yang 
berulang kali menyatakan bahwa kesepakatan tersebut sangat lemah dan mengancam akan membawa AS keluar dari JCPOA. Mattis mengatakan bahwa "the deal, known as the Joint Comprehensive Plan of Action, isn't perfect, but that staying in it would be in America's national security interest” (Mitchell 2018).

Selain itu pandangan yang berbeda dengan Trump juga muncul dari kalangan militer AS, Kepala Komando Sentral AS Joseph Votel mengatakan kepada Senat Armed Services Committee pada 13 Maret bahwa ia memiliki pandangan yang sama dengan Menteri Pertahanan Jim Mattis dan Ketua Kepala Staf Gabungan Joseph F. Dunford bahwa kesepakatan itu masih untuk kepentingan terbaik Amerika Serikat. Jenderal Dunford berranggapan bahwa Iran tidak melanggar JCPOA dan kesepakatan tersebut untuk menghalau Iran mengembangkan senjata nuklir (Gibbons-Neff \& Sanger 2018). Akhirnya James Mattis, Joseph Votel juga diturunkan dari posisinya.

Cognitive Consistency dalam hal ini menjelaskan tentang bagaimana persepsi memengaruhi pengambilan keputusan. Pembuat keputusan mengecilkan informasi tertentu yang tidak konsisten dengan images dan beliefs sebelumnya yang ia miliki atau pembuat keputusan memberi perhatian yang berlebihan terhadap informasi yang konsisten dengan images dan beliefs tersebut (Alex \& DeRouen Jr 2010). Keadaan seperti ini menyebabkan pembuat keputusan cenderung mengabaikan informasi yang bertentangan dengan apa yang sudah mereka yakini sebelumnya. Dengan kata lain informasi yang diterima akan diproses sesuai dengan "images yang sudah ada" (Jervis 1976; Alex and DeRouen Jr 2010). Bagi Trump, hal yang paling penting adalah menemukan dan menciptakan Informasi yang konsisten dengan gambaran dan keyakinan sebelumnya yang sudah ia miliki tentang buruknya kesepakatan nuklir antara AS dan Iran, sedangkan Trump sangat membatasi pencarian informasi lainnya yang berisi alternatif kemungkinan lain.

Jervis menyimpulkan bahwa perangkap konsistensi kognitif dapat menyebabkan pembuat keputusan menjadi terlalu percaya diri dalam posisinya dan mengabaikan sudut pandang alternatif yang penting. Sejalan dengan kesimpulan Jervis, Donald Trump sejak masa kampanye menyatakan bahwa kesepakatan nuklir Iran merupakan kesepakatan terburuk dan memalukan yang pernah dicapai oleh Amerika Serikat. Ketika Trump berhasil memenangkan pemilihan pandangan tersebut tidak berubah meski mendapat saran dan informasi yang berbeda dari lingkar dalam yang ada di dalam admisnistrasinya. Ketika Trump memecat para pejabat 
pemerintahan seperti Menteri Luar Negeri Rex Tillerson, Penasihat Keamanan Nasional HR McMaster, Menteri Pertahanan James Mattis dan Kepala Komando Sentral AS Joseph Votel, yang memiliki pandangan yang berbeda dengan dirinya terkait kesepakatan nuklir Iran (CNN Indonesia 2018). Terlihat kecenderungan Trump untuk mengabaikan informasi yang tidak sesuai dengan persepsi yang ia miliki. Pertimbangan-pertimbangan alternatif lain yang berisi saran dan pandangan yang berbeda tidak menjadi perhatian Trump. Hal tersebut tidak lepas dari besarnya peranan faktor psikologis cognitive consistency Donald Trump dalam memutuskan kebijakan

Donald Trump yang sama sekali tidak memiliki rekam jejak berada di public office ataupun military service memiliki pengalaman bisnis yang sukses dalam hidupnya. Pengalaman tersebut pasti sangat mempengaruhi perilaku dan gaya pengambilan kebijakannya, jiwa pebisnis Trump dalam kasus penarikan diri dari JCPOA memiliki peranan yang cukup kuat dalam upaya penekanan yang terus dilakukan terhadap Iran dengan tujuan agar Iran mau menuruti apa yang AS inginkan. Prinsip take and give dalam kesepakatan ala Trump sangat erat dengan perhitungan untung-rugi yang diperoleh JCPOA dalam kacamata seorang pebisnis. Jika dibandingkan dengan administrasi sebelumnya, Presiden Obama memilih untuk membawa Iran kedalam perundingan dan membuat kesepakatan meskipun memberikan sedikit keuntungan daripada tidak ada sama sekali. Hal ini dilihat berbeda oleh Trump, Iran menjadi pihak yang terlalu diuntungkan, dan bagi Trump siapapun yang mencoba memanfaatkan atau mengambil keuntungan darinya akan mendapatkan perlawanan yang sangat keras darinya. Trump sebagai pebisnis memiliki target yang harus dicapai, dan ia akan terus melakukan penekanan-penekanan sampai keinginanya tercapai. Sikap seperti inilah yang ia bawa kedalam pemerintahannya terlebih dalam menghadapi Iran.

\section{Analisis Eclecticism antara Dilema Keamanan dan Cognitive Consistency}

Dengan menghubungkan kedua perspektif yang berbeda ini pendekatan analytic eclecticism akan mengeksplorasi jembatan yang menghubungkan keduanya. Baik security dilemma maupun cognitive consistency adalah perspektif yang sama-sama terkait dengan persepsi, images dan kepercayaan. Dalam kasus keluarnya AS dari JCPOA, terdapat kekhawatiran terhadap ancaman yang 
muncul atas pengembangan kekuatan militer Iran. JCPOA pada kenyataannya tidak menghilangkan perilaku agresif Iran seperti apa yang telah dikatakan para pihak penandatangan kesepakatan yang masih berupaya menjaga JCPOA untuk tetap hidup dan bertahan. Ketidakamanan dan kerentanan terhadap ancaman dari negara lain merupakan sebuah persepsi yang secara konsisten menganggap negara lain tersebut merupakan ancaman bagi negaranya.

Jika AS dan sekutunya tidak menganggap Iran sebagai musuh, upaya pengembangan rudal balistik yang mereka lakukan setelah JCPOA diterapkan adalah hal yang biasa saja, tidak perlu direspons sebagai sebuah ancaman yang nyata. Berdasarkan analisis sebelumnya pada bagian security dilemma bahwa Iran melakukan beberapa kali percobaan peluncuran rudal balistik yang mereka anggap sebagai alat memperkuat keamanan yang merupakan kepentingan negaranya. Bagi AS, meningkatkan tekanan terhadap Iran akan membatasi pengaruh destabilisasi Iran di kawasan Timur Tengah dengan harapan bahwa meningkatkan tekanan dapat memaksa Iran kembali ke meja perundingan untuk melakukan renegosiasi yang tidak sekedar menunda tetapi sekaligus menghilangkan ancaman nuklir dan rudal balistik Iran.

Sedangkan di sisi lain analisis cognitive consistency dari psikologis Trump menghasilkan fakta bahwa Trump cenderung mengabaikan alternatif lain yang berisi informasi lain yang bertentangan dengan images dan beliefes yang sudah iya yakini terkait kesepakatan nuklir Iran. Trump tidak mendengarkan pendapat yang berasal dari lingkar dalam pemerintahannya untuk tetap menerapkan JCPOA. Ia memilih untuk konsisten dengan keyakinan bahwa JCPOA merupakan kesepakatan yang membawa bencana bagi AS, Israel bahkan Timur Tengah secara umum dan AS harus mengakhiri keikutsertaannya dari JCPOA.

Persepsi ancaman dan pre-existing images and beliefes yang dimiliki Trump menghantarkan pada kesimpulan yang memadukan kedua teori security dilemma dan cognitive consistency. Konvergensi yang ada diantara dua perspektif berbeda ini adalah keduanya samasama memuat persepsi yang menyebabkan munculnya keharusan untuk bertindak, tindakan tersebut kemudian diwujudkan melalui sebuah kebijakan. Dengan kata lain kondisi security dilemma yang masih dirasakan meskipun Iran sudah berada di bawah JCPOA mendorong AS untuk melakukan sesuatu. Selanjutnya terjadi asimilasi antara informasi lingkungan eksternal (security dilemma) dengan pre-existing images and beliefes yang dimiliki oleh Trump. 
Pada akhirnya Trump yang sebelumnya sudah memiliki pandangan buruk dan skeptis terhadap JCPOA semakin teguh pendiriannya ketika melihat kondisi yang terjadi.

\section{Kesimpulan}

Penarikan diri AS dari JCPOA secara psikologis disebabkan konsistensi pemikiran Trump yang memandang kesepakatan nuklir Iran sebagai kesepakatan yang buruk dan tidak bisa diandalkan karena di bawah kesepakatan nuklir AS dan sekutunya masih merasakan dilema keamanan yang kemudian mendorong Trump berupaya untuk menekan Iran dengan keluar dari kesepakatan nuklir. Trump tidak mempertimbangkan alternatif lain, ia hanya memaksimalkan pandangannnya terkait buruknya JCPOA dan AS harus mengakhiri keterlibatannya. Hal tersebut dapat dilihat dari sikap Trump yang cenderung mengabaikan pandangan yang bertentangan dengan apa yang sebelumnya sudah ia yakini, terbukti dari pemecatan orang-orang penting yang seharusnya ia dengar dalam administrasinya, Sekretaris Negara Rex Tillerson, Penasehat Keamanan Nasional HR McMaster dan Menteri Pertahanan John Mattis. Trump lebih memilih mengangkat orang yang memiliki pemikiran sama dengan dirinya. Trump terjebak dalam perangkap kognitif yang ia ciptakan sendiri yang kemudian membuat dirinya terlalu percaya diri terhadap keputusan yang ia ambil.

Proses pembuatan kebijakan Trump yang semacam ini menyebabkan kebijakan yang ia ambil cenderung irasional. Tampaknya Trump salah melakukan penilaian bahwa upaya penekanan keras terhadap Iran akan melunakkan sikap Iran, bahkan satu tahun setelah AS keluar dari JCPOA menunjukkan fakta bahwa semakin besar ambisi AS menekan Iran, semakin besar perlawanan dan kegagalan serta konsekuensi yang tidak diinginkan. Dalam kasus keluarnya AS dari JCPOA bahkan tidak ada negara peserta penandatangan kesepakatan yang mendukung langkah Trump. 


\section{Daftar Pustaka}

\section{Buku atau Artikel dalam Buku}

Alex, M., \& DeRouen Jr, K. (2010). Understanding Foreign Policy Decision Making. United States of America: Cambridge University Press, New York.

Trump, D. J., 1987. The Art of the Deal. New Yorks : Ballantine Books.

\section{Artikel Jurnal}

Berni, H. M., 2018. "Iran's Security Dilemma in The Middle East :A Neorealist Approach to Iran's Foreign Policy in Syria", The Journal of Iranian Studies, 1(2): 115-139.

Nainggolan, P.P.(2015). "Kesepakatan Nuklir Iran dan Implikasinya”, Info Singkat Hubungan Internasional, 7 (15): 5-8.

\section{Tesis dan Laporan Resmi}

IAEA, 2016. Verification and monitoring in the Islamic Republic of Iran in light of United Nations Security Council resolution 2231 (2015).

Katzman, K., 2018. "Iran's Foreign and Defense Policies", Congressional Research Service.

Saï, A., 2016. "Iran And The United States' Relations In The Context Of The Nuclear Deal”, Tesis Master. Prague: Faculty of Social Sciences Charles University in Prague.

\section{Publikasi Daring}

BBC, 2016. "CIA chief warns Trump: Scrapping Iran deal 'height of folly"' [daring]. Tersedia dalam https://www.bbc.com/news/ world-us-canada-38149088 [diakses pada 13 April 2017]

BBC, 2018. "HR McMaster: Why did Trump dump national security adviser?” [daring]. Tersedia dalam https://www.bbc.com/ 
news/world-europe-39033934 [diakses pada 10 April 2019].

BBC Indonesia, 2018. "Kesepakatan nuklir Iran: Usaha penyelamatan oleh Eropa", 12 Mei [daring]. Tersedia dalam https://www. bbc.com/indonesia/dunia-44080139 [diakses pada 28 September 2018].

Business Insider, 2015. "Donald Trump explains the give-andtake of deal-making like only he can" [daring]. Tersedia dalam https://www.businessinsider.sg/donald-trumpdeals-2015-11/?_ga=2.213852884.134617975.1557895914336006491.1557239881\&r=US\&IR=T [diakses pada 4 Mei 2019].

CNN, 2019. "In Tehran, specter of war met with more defiance than fear" [daring]. Tersedia dalam https://m.cnn.com/ en/article/h_c15f1ce4b4ed6552do9e58fa58197a9e [diakses pada 17 Mei 2019].

CNN Indonesia, 2018. "Trump Siap Pecat Penasihat Keamanan Nasional AS” [daring]. Tersedia dalam https://www.cnnindonesia.com/ internasional/20180316093923-134-283496/trump-siappecat-penasihat-keamanan-nasional-as [diakses pada 8 November 2018].

Erik Slavin, 2014. "Iran Emphasizes Nuclear Reconciliation, Criticizes U.S. Military Posture in Persian Gulf", Stripes [daring]. Tersedia dalam http://www.stripes.com/news/ iran-emphasizes-nuclear-reconciliation-criticizes-usmilitaryposture-in-persian-gulf-1.271204 [diakses pada 1 Mei 2019].

Gibbons-Neff, T. Dan D. E. Sanger, 2018. "Mattis Contradicts Trump on Iran Deal Ahead of Crucial Deadline", New York Times [daring]. Tersedia dalam https://www.nytimes. com/2017/10/03/world/middleeast/mattis-iran-dealtrump.html [diakses pada 6 April 2019].

McLaughlin, E., 2018. "Tillerson's support for Iran deal helped get him fired, but Mattis shares his views", ABC News [daring]. Tersedia dalam https://abcnews.go.com/Politics/ tillersons-support-iran-deal-helped-fired-mattis-shares / story?id=53712207 [diakses pada 6 April 2019]. 
Mitchell, E., 2018. "Mattis defends Iran deal as Trump considers withdrawal", The Hill [daring]. Tersedia dalam https:// thehill.com/policy/defense/385094-mattis-defends-irandeal-as-trump-considers-withdrawal [diakses pada 6 April 2019].

Reuters, 2016. "Trump election puts Iran nuclear deal on shaky ground" [daring]. Tersedia dalam https://www.reuters. com/article/us-usa-election-trump-iran/trump-electionputs-iran-nuclear-deal-on-shaky-ground-idUSKBN13427E [diakses pada 2 Mei 2019].

Rferl, 2018. "Pentagon Voices Support For Iran Nuclear Deal Amid Tillerson Exit" [daring]. Tersedia dalam https://www.rferl. org/a/pentagon-general-votel-voice-support-iran-nucleardeal-tillerson-exit-/29097758.html [diakses pada 10 April 2019].

Suastha, R. D., 2017. "Balas Sanksi AS, Iran Berencana Tambah Anggaran Rudal", CNN Indonesia [daring]. Tersedia dalam https://www.cnnindonesia.com/ internasional/20170813192122-120-234433/balas-sanksias-iran-berencana-tambah-anggaran-rudal [diakses pada 11 Maret 2019].

Telegraph, 2018. "Donald Trump announces 'withdrawal' From Iran nuclear deal" [daring]. Tersedia dalam https:// www.telegraph.co.uk/news/2018/05/o8/donald-trumpannounces-decision-iran-nuclear-deal-live-updates / [diakses pada 28 September 2018].

Telegraph, 2018. "UK, France and Germany pledge to remain in Iran nuclear deal as US withdraws" [daring]. Tersedia dalam https://www.telegraph.co.uk/news/2018/05/o8/uk-francegermany-pledge-remain-iran-nucelar-deal-us-withdraws/ [diakses pada 8 Mei 2018].

Time, 2016. "Read Donald Trump's Speech to AIPAC" [daring]. Tersedia dalam http://time.com/4267058/donald-trumpaipac-speech-transcript/ [diakses pada 4 Mei 2019].

Time, 2018. “'We Disagreed on Things.' Read President Trump's Remarks After Firing Rex Tillerson" [daring]. Tersedia dalam https://time.com/5197334/we-disagreed-on-thingsread-president-trumps-remarks-after-firing-rex-tillerson/ 
[diakses pada 13 April 2019].

White House Office of the Press Secretary, 2017. "Remarks by President Trump to the 72nd Session of the United Nations General Assembly" [daring]. Tersedia dalam https://www. whitehouse.gov/briefings-statements/remarks-presidenttrump-72nd-session-united-nations-general-assembly/ [diakses pada 12 Maret 2019].

White House, 2017. "Remarks by President Trump on Iran Strategy" [daring]. Tersedia dalam https://www.whitehouse.gov/ briefings-statements/remarks-president-trump-iranstrategy/ [diakses pada 4 Mei 2019].

White House, 2018. "Statement by the President on the Iran Nuclear Deal" [daring]. Tersedia dalam https://www.whitehouse. gov/briefings-statements/statement-president-irannuclear-deal/ [diakses pada 4 Mei 2019]. 
Konfrontasi Amerika Serikat dan Iran dalam

Joint Comprehensive Plan of Action (JCPOA) 